\title{
Ascertaining Causes of Death: A Comparative Study of the Ika of Delta State and the Obolo of Rivers State
}

\author{
Wilson E Ehianu* and Finomo Julia Awajiusuk ${ }^{\dagger}$
}

\begin{abstract}
The cut and thrust of this paper is the re-examination of an age long belief and practice among the Ika people of Delta State and the Obolo of Rivers State which is aimed at discouraging the practice of witchcraft and sorcery. The study critically evaluates the phenomenon which includes necromancy, divination and poison ordeal and concludes that caution is needed as the act which involves human life is not without imperfection. The discourse is comparative as it examines the methods of ascertaining death among the Ika and Obolo. It employs moral, social and philosophical springboards for the analysis. Some of the findings includes: belief in witchcraft is very strong among the people and age long practices to eradicate same will endure, if nothing is done to discourage it. A major constraint is that matters relating to witchcraft and sorcery are metaphysical and so difficult to verify.
\end{abstract}

Keywords: Death, Ascertain, Cosmology, Necromancy, Divination and Ordeal by poison

\section{Introduction}

Perhaps no belief is as strong and widespread among Africans as the belief in the causal connection of events.

* Department of Philosophy and Religions, University of Benin, Nigeria

+ Department of Religious and Cultural Studies, University of Port Harcourt, Nigeria; juliafinomo@gmail.com 
For Africans there can be no smoke without fire. Consequently, every phenomenon oroccurrence adjudged unpleasant or mysterious is attributed to some extraneous forces. In this regard witches, wizards, sorcerers or malevolent and provoked deities readily come to mind. However, these forces cannot all be responsible for a single evil at the same time. Hence investigation is required in order to narrow down an evil to its specific cause(s). If traced to the machination of witches or sorcerers it is visited with appropriate sanctions to serve as a deterrent to other members of the community. Incidentally the Ika of Delta State and the Obolo (Andoni) of Rivers State being Africans themselves share the aforementioned beliefs with other Africans.

In this paper, we outline the processes involved in determining the cause(s) of sudden or mysterious deaths in Ika land comparing this with what obtains in Obolo (Andoni). The paper is interdisciplinary as insights are derived from anthropology, history, metaphysics and sociology. A multidimensional approach of religious studies is employed. These are the historical and phenomenological approaches. Historical as the study is carried out in time perspective and phenomenological to allow data speak for themselves. The paper argues that there is a similarity between the beliefs of the Ika of Delta State and the Obolo (Andoni) of Rivers State in ascertaining cause(s) of death. On the other hand, the paper observes that there is need for caution as such matters center on human life and psyche. For the purpose of clarity, this work is couched in this order; the meaning and types of death, methods of determining the causes of death and the implications of such processes for both the culprit and the society. The work is thereafter evaluated and concluded.

\section{Obolo Cosmology}

In Obolo world-view, the idea of the Supreme Being is not totally absent. The people awed by the vast expanse of the Atlantic Ocean called it emen-Awaji (the depth of God). ${ }^{1}$ The idea of the Supreme

1 F. J. Awajiusuk, Religio-Cultural Change in Obolo (unpublished), MA Thesis, Department of Religious and Cultural Studies, University of Port Harcourt, 2006, 38. 
Being may be hazy but not strange in Obolo religious thought. On the contrary, he can be said to be a Deus Remotus as Horton pointed out concerning his existence in African Cosmology. ${ }^{2}$ The second spirit world which is occupied by the ancestors (Ebi-ugaene) can only be occupied through death and burial; thus resulting in the prominence given to first and second burials. It is the belief of the people that the type of burial given to the deceased is a sine-quanon to how he will be treated in the spirit world. Death in Obolo religious thought is seen as a transition into the spirit world. This, accounts for certain bizarre funeral rites such as the burying of slaves alive with their masters, burying of treasure with people of high social standing in society, as done in Unyeanda Community particularly. There is no death without a cause. ${ }^{3}$

Reincarnation is a prominent feature of the Obolo cosmology. Elders who led good lives are believed to reincarnate in their families. Such elders join the ancestors. The ancestors protect family members while warning them against impending dangers. As a result of the belief in reincarnation, there is a belief in born-todie children called bong-ugawaji (children of spirit mothers). This is similar to Abiku in Yorubaland and Ogbanje in Igboland. Their spirit mothers are believed to come for them at will. Hence, they keep repeating the cycle by dying and coming back. To emphasize their belief, Mrs. Fanny Orubong recounted her ordeal. She stated that she had a daughter who repeated the cycle several times, at a point she had to give the dead child a mark. At birth the next child she had came with the fresh wound at the exact point where she had cut the last child. The latter survived. ${ }^{4}$

\section{Ika Cosmology}

In most traditional communities, Ika in particular, God (Chineke, Chukwu, Osolobue in Ika language) is believed to be the creator and sustainer of the universe. Such theophoric names as Chukwueku

${ }^{2}$ R. Horton, “African Conversion”, Africa Vol.41/2 (April 1971), 208.

${ }^{3}$ F. J. Awajiusuk, Religio-Cultural Change in Obolo, 38.

${ }^{4}$ Orubong, Interview: Feb 1, 2012. Mrs. Fanny Orubong is an 83 year old woman who lost several children and decided to put a stop by mutilating the body of one. 
(God decides), Chukwuma (God knows), Chineke (God creates), Chiwendu (God owns life), Osolobue (God sustains the universe) and numerous others attest to the centrality of God among the Ika people. Man in Ika cosmology is believed to be a tripartite being. He is made up of the body, soul and spirit. The essence of the soul in man is to make him recognize and give expression to divine revelation. Further still, man is created with freewill which he is expected to put to positive use fellowship with God, other people and society in which he lives.

In direct opposition to God is the devil who is pitted against God and creation in general. However, unlike God the devil is disadvantaged in the sense that he does not possess the power of omnipresence. So, he issues his power into persons who became his agents. Witches and sorcerers are believed to be the commonest agents of the devil and he uses them to inflict harm, misfortune and death on people. There is also the believe that one of the devils strategies is to influence someone to neglect his/her filial duties to the ancestors, break taboos and sanctions of the divinities so as to incur their wrath. The manner witches, sorcerers and deviants are treated in Ika land clearly attests to the people abhorrence for the devil and his accomplices.

\section{The Meaning and Types of Death among the IKA and the Obolo}

Ashibuogu writing about the Igbo of Eastern Nigeria, a people who share a common culture with Ika of Delta State postulates that death means "going home". He goes further to say that not all who die reach home as the type of death indicates a proper arrival home or not ${ }^{5}$. Three types of death await an Ika person: he may either die a natural death (onwuehi), a violent death or devil's death (onwu $i k e n)$, or a bad death (eje-onwu). In the same discourse, Ashibuogu posits that the last two kinds of death are often attributed to malevolent powers - witches, wizards, sorcerers, broken taboos or oath, angry deities, failure to carry out ones filial duties to the

5 U. E. Ashibuogu, "Suicide in Christianity and Igbo Culture: A Comparative Study" (unpublished), B. A. Thesis, Lagos State University, 1990, 34. 
ancestors and sundry causes. These are mortally detested and a man would spend all he has in sacrifice in order to prevent it. The manner of death notwithstanding, every death must be investigated to ascertain the cause(s) as this serves to reveal the entitlement of the deceased in terms of burial rites; a practice which in the words of Rose "is a little short of universal." 6

Among the Obolo, there are also three types of death. First is natural death (nkpa Awaji). Literally this means God's death. Second is violent death (nkpa unye). This occurs when an individual dies suddenly. Some die foaming in the mouth or vomiting blood. The person may not have been really sick but feels a sharp pain in the chest shouts and gives up the ghost. Third is bad death (ijo $n k p a)$. This occurs through accidents such as drowning in the rivers or Atlantic Ocean or motor accident. People who die from the swelling disease are also said to die bad Deaths. People who die this way are not given proper burials but thrown into the evil forest

\section{Determining the Causes of Death}

Investigating the cause of death in Ika as well as in Obolo takes one or two of the following forms. These forms are discussed below.

\section{a) Necromancy}

Necromancy is a derivation from the Greek words nek'ro man-s meaning nekroas-a dead body and manteia-divination. Put together, the word means "the art of divining [...] by conjuring up the spirits of the dead, questioning them concerning issues of evil occurrences that cannot ordinarily be determined by human senses ${ }^{7}$. The ancient rite of necromancy is practiced by many people in the world. The Old Testament makes mention of it in Deuteronomy 18: $10-11$ but forbids it. In 1 Samuel 28, the well known story of the witch of Endor who called up the spirit of Samuel at the request of Saul is narrated. In the $11^{\text {th }}$ book of Homer's Odyssey, it is reported

${ }^{6}$ H. J. Rose, "Death" in Encyclopaedia of Religion and Ethics, Vol. IV, New York: Charles Scribner's Sons, 1971, 775.

7 C. O. Isiramen, "Necromancy: A Socio-Religious Practice among Otuo People of Nigeria" in Epha, Ekpoma Journal of Religious Studies, Vol. 6, (2010), 114. 
that Odysseus brought up the shade of Tiresias and consulted it. Necromancy was abundantly practiced in most parts of ancient Greece by Priests and other religious functionaries in their temple through the Oracles of the dead. A professional class known as "Psychogogi" was in charge of necromantic practices in Thesslay. ${ }^{8}$

The practice of necromancy in Ika is peculiar in the sense that the dead takes more active part in revealing the cause(s) of death. This practice is called Ima-Ozun. Literally ima ozum means "measuring the corpse". When a person dies, the corpse is given the customary bathing, dressed and put in a coffin. In the event of the death of an Ika in such a circumstance that it becomes impossible to return the corpse home, palm frond (Omu) is used to brush the corpse, symbolically invoking the spirit into the palm frond which is taken home and put in a coffin. This is called iju-omu among the Ika people. ${ }^{9}$

Only the teethed are eligible for necromancy. However, should a child who has not cut a tooth die in suspicious circumstances and the family is bent on knowing the cause of such death, the grains of corn may be put in the mouth of the dead child. The grains of corn which signify teeth qualify the dead child to go through the act of necromancy. The corpse or palm frond with certain leaves is put in a coffin which is placed on the head of two middle aged men who would have taken an oath of sincerity and transparency. At this stage, certain rituals and incantations are made in order to rouse the spirit of the dead. This spirit of the person is called seven times by its native name to come forth and defend itself.

The deceased is believed to have led a bad life until $\mathrm{h} /$ she proves him/herself to the contrary. This is a moment of great fear for members of the family as their image and future depends largely on the outcome of this "diagnosis". A particular charm is rubbed on the feet of these men who become ecstatic and immune to any harm according to the belief of the people. The deceased is said to have answered in affirmative when it moves the men to hit the coffin on the wall or nods affirmatively. When the response is

8 C. O. Isiramen, “Necromancy,” 114.

9 B. Oviah, Personal Interview, Traditional Chief, Owa land, Owanta, 2005, C. 73 years. 
negative, the coffin shakes but does not move. By so doing, information concerning the dead man, viz the cause of his death, how his property is to be shared among his children (this happens when crisis of inheritance is perceived) are obtained. Revelations concerning problems facing the communities may also be sought in this process.

There is the belief that at death one knows no shame. So, to call someone Ozun (dead body) is the same thing as saying one is shameless. In Ika land, it is not uncommon to hear people say "he who does not speak the truth while alive will do so unconsciously at death"10. The practice of necromancy is believed to serve as a deterrent to evil-doers. Quite often we hear children tell their parents not to sling mud on them i.e. they should no indulge in evil acts as this would be exposed to the shame of those they leave behind. There is also the belief that whoever is buried in the evil forest does not join the community of ancestors. It is the earnest desire of every Ika man to be re-united with his departed parents at death. Through necromancy possible dangers are foreseen and necessary steps are taken to avert them.

Among the Obolo like it is among the Ika necromancy is a common practice. This act is employed in the bid to ascertain causes of deaths. To ascertain the cause of death, members of the deceased's family contact a native doctor. The native doctor calls up the spirit of the deceased. The spirit of the deceased exposes everything concerning his/her death. This comes from the belief of the people that everything is open to the dead. Before leaving their homes to consult the native doctor the people pour libation asking the dead to bring to fore whatever and whosoever may be responsible for his/her death. When the spirit of the deceased is called up, family members ask pertinent questions concerning cause of death and the likelihood of another member of the family dying.

\section{b) Divination}

This is defined as the effort to obtain information about things concerning the future or otherwise removed from ordinary

10 W. E. Ehianu, "Ecumenism in Owa Land" (unpublished), Edo State University, Ekpoma, 1997, 6. 
perception by consulting informants other than human ${ }^{11}$. The observation by Rose that divination is practiced by the more backward races of mankind and by uneducated members of the civilized people can only be half-truth given the obvious reality that some civilized and educated people when faced with life challenges discretely and clandestinely resort to this practice ${ }^{12}$. In Ika, recourse is made to divination when a person is declared missing in which case the corpse is not available for necromantic practice. In a bid to ascertain the manner of burial rites to accord the presumably dead, the diviner is consulted. Note that the presumably dead could be ritually buried even when the corpse cannot be found.

The Obolo also practice the act of divination. Diviners are consulted for varied purposes especially to ascertain cause(s) of death. It implies ascertaining the cause(s) of death by invoking the deities. This is basically because the cause(s) of death determines the type of burial a deceased would be accorded. If the individual died a natural death, he/she will be given an elaborate burial. If it is discovered that the individual died from the activities of juju or the individual was involved in diabolical activities, then sacrifices must be offered before such a one is buried.

\section{c) Ordeal by Poison}

Among the Ika when a person dies in circumstances adjudged mysterious, relatives of the deceased may be compelled to undergo the Ordeal Poison. Rose records that among the Bantu of East Africa Ordeal takes the form of an oath upon the ashes of the fire at which the funeral food is cooked. ${ }^{13}$ In Ika, relatives of the deceased may be forced to drink from the bath water of the corpse. According to the people's belief the culprit dies soon after this ordeal. In some cases, witchcraft suspects are taken to medicine men who administer the poison ordeal to prove the innocence or otherwise of the suspects. The suspect is said to be guilty if after taking the Poison he/she begins to exhibit signs of insanity, his/her lips become fat and

${ }^{11}$ W. E. Ehianu, "Ecumenism in Owa Land," 6.

12 H. R. Rose, "Death," 775.

${ }^{13}$ H. R. Rose, "Death," 776. 
tongue distends. The culprit in this state may begin to confess his/her witchcraft activities or simply own up to charges against him/her.

Unlike the Ika the traditional Obolo do not believe that relatives can or do poison one another. Witchcraft and sorcery are not common practices in Obolo. The predominant practice is the act of pouring salt water in a person's house. The salt water is believed to be the abode of oke or adumung (the water deities). This deity kills relations of victims especially prominent ones. Until the deity is appeased, deaths continue to occur in the family of the victims.

In times past, witches among the Ika were either stoned to death by an angry mob, poisoned secretly or killed in the bush and thereafter declared missing. There is, however, an exception. A witch that is believed to posses rare potentials may not be killed. Instead, he/she may be required to go through the rituals of becoming an оти. An Оти is a witch that has taken an oath before the community deity not to kill or destroy any longer but to protect and alert the community of any impending danger. ${ }^{14}$ Writing about witchcraft among the Nupe of Middle Belt of Nigeria, Nadel described the "Lelusagi", the equivalent of Omu in Ika land in this way:

She is held to be a "good" witch, who would employ her secret knowledge for the good of the community. Whether she had "reformed" before being entrusted with the responsibility of her office or whether this caused her moral reform, is not a question the Nupe ask themselves; but equally she must "have' "witchcraft" to fill her office. For this consist on the mystic plane, in controlling her colleagues, restraining their nefarious activities, warning the chiefs of the presence of alien witches and generally acting as his trusted agent in these matters. ${ }^{15}$

In time past among the Obolo a witch is impaled at Ichiama a place that can rightly be termed the Golgotha of the Obolo. With time

14 W. E. Ehianu, "Ecumenism in Owa Land," 6.

15 S. F. Nadel, Nupe Religion, London: Routledge and Kegan Paul Ltd., $1954,16$. 
each community developed her own Golgptha (the evil forest). People with evil tendencies are thrown into this forest. Most of them are impaled in the evil forest and pin to the ground upside down. ${ }^{16}$

The essence of diagnosing the cause(s) of death among the Ika and the Obolo is to determine whether the deceased died a "good death" or a "bad one". This is because the manner of death frequently determines the burial rites to be performed since it determines the fate of the deceased in the other world. Rose suggests that,

The chief object of the proper disposal of the corpse and the fulfillment of all the rites and custom in connexion therewith are to free the living from the defilement of death and to give rest to the deceased. Until they are all ended, the soul is not finally dismissed to its place in the other world, it is not reunited to the company of the father, it is not elevated to its due position in the household or tribal cult and it continues to hunt the survivals unpleasantly. ${ }^{17}$

\section{Evaluation}

The practice of diagnosing the cause(s) of death among Ika people is premised on the belief in the evil of witchcraft and the need to eradicate its practice. The belief that the spirits of witches, wizards, sorcerers and other evildoers who are buried at home torment members of their family informs the need for the right "diagnosis" and appropriate burial. As suggested by Rose, such a belief is "a little short of universal."18 Ashibuogu shares this view when he writes: "In Christian Europe, suicide was equated with witches and war locks and their corpses seen in the same light...they were buried at crossroads with stakes driven through their heart to prevent their ghost from causing harm." 19

${ }^{16}$ F. J. Awajiusuk, Religio-Cultural Change in Obolo, 34.

${ }^{17}$ H. R. Rose, "Death," 776.

18 H. R. Rose, "Death," 419.

19 U. E. Ashibuogu, "Suicide in Christianity and Igbo Culture," 34. 
The undesirability of evildoers, of which witches are believed to form the bulk is reflected in the way confirmed witches are treated dead or alive. Middleton describes witches thus:

Witches are "inverted" beings within a field of social relations [...] who have perverted normal relations of kinship and authority. They deny and destroy ties of kinship and neighbourhood and so deny and destroy the ties that are necessary for the existence of any kind of orderly social life. ${ }^{20}$

Researches have shown that there is hardly any society where witchcraft and sorcery are permitted. However, what appears to be lacking is a method or procedure for trying suspects before they are confirmed guilty or innocent. Inagbor must have noticed this amongst the Okulosho people when he writes: "It should be made clear that the system is imperfect, hence they have to retest some deceased to find out whether they are to remain at home where they were buried or exhumed and taken to bush or be buried there. So, the system itself is imperfect and defective." 21

Obvious imperfection and ambiguities in the method of diagnosing the cause of death and the manner in which sanctions are administered explain the wide spread campaign for caution especially as death or banishment is the penalty for any man or woman who is "proven" to be a witch or sorcerer. The former is restricted to the individual while the latter may involve an entire household. The implication is that innocent persons may suffer the penalty of witchcraft just because a member of the family has been adjudged to be a witch.

Thus, families abound in Ika which are avoided in social relations marriage, social works and positions of trust. It is possible to find families where there are numberless men and women who are of

${ }^{20}$ J. Middleton, Lugbara Religion, Oxford: International African Institute, 1960, 44.

${ }^{21}$ V. Inagbor, "The Mythological Concept of Death and After Life: An Evaluation of Aspect of Okulusho Metaphysics" (unpublished), M.A. Thesis, Edo State University, Ekpoma, 1988, 72. 
good character and of marriageable age but are unmarried just because one or two members of their family have been fingered to be witches. Women are usually the worse hit. While we agree that most witches were inducted into the cult by their family members, certain questions must be raised. Is it not possible for a child whose parent is a witch to be free from witchcraft? Or is witchcraft contagious and infectious? How long will the community remain nonchalant and watch businesses crumble for lack of patronage just for the mere fact that the manager of such a business or his close relative has been accused of witchcraft? These are questions yearning for answers.

The plight of perceived witches is made more pathetic by the current practice of excommunicating them from the church and Christian organizations. In Ika land, the list of perceived witches who have been so excommunicated is endless.

Apparent ambiguities in the concept of witchcraft and the glaring imperfections in the method of establishing a case of witchcraft have led some persons to doubt its very existence. Nadel puts it quite succinctly. He writes:

Some see witchcraft as a projection or displacement of hatred and aggressive desires from the sphere of rational social life into one mystically sanctioned. Through such projections and displacement, the doctrine of witchcraft both permit anxieties to become articulate and shows them an outlet, or scapegoat. ${ }^{22}$

While we may not subscribe to this view which is rather extreme, it is pertinent to stress that it is safer to bury the dead un-investigated than to shed innocent blood. There is the need for caution in these practices especially as human life and psyche are involved. More vigorous checks and balances should be put in place to ensure that before someone is declared a witch, his/her involvement is self evident and beyond reasonable doubt.

The practice of ascertaining the causes of death among the Ika and the Obolo is premised on the need to discourage and perhaps eliminate individuals who are believed to inflict misfortune and

22 S. F. Nadel, Nupe Religion, 16. 
death on their fellow community members. As seen in this study witches and sorcerers are believed to be behind most, if not every evil occurrence in the land. This idea must be revisited in the light of scientific discoveries. For instance, until recently many did not know that most deaths often traced to water spirits (Ogbanje) among children were caused by sickle cell anaemia, a medical condition caused by wrong genotype combination. We quote in extenso Isiramen's pathetic story of the ill treatment suffered by four women found "guilty" of causing multiple deaths in a family who were eventually vindicated by laboratory findings:

On the $8^{\text {th }}$ of March, 2005, Mrs. Esohe Ogbeide of Ujemen, in Ekpoma, Edo State, died at her residence from a long term mysterious and unresolved persistent ailment. It started with body pain, headache, then malaria, then typhoid fever, then diarrhoea and so on until she finally died. A year later, her husband, Mr. Oboite Ogbeide died of similar symptoms. Three months later, their 20 year old daughter, Miss Grace Ogbeide, died of similar symptoms. Almost immediately, Jonathan, one of the sons of late Mr. and Mrs. Ogbeide also died of similar symptoms. The remaining members of both nuclear and extended family of Ogbeide were gripped with fear and they took to their heels and relocated, exclaiming in unison: "These deaths occurring consecutively must have a demonic undertone. A merciless witch is after the family and has vowed to wipe out the entire family of Ogbeide". Fear, anxiety, suspicion, rumour mongering, discussions in various small groups concerning who the witch or witches could be, had a field day. "What do we do?" wailed an elder of the family. "Hospital definitely does not have solution to this problem", they concluded. The reason for the deaths in Ogbeide's family was easily 'identified'. They claimed that some jealous witches got angry and began to eliminate the Ogbeides because their son in America bought a new car for them and also built a house into which they recently packed. The question was: "who were these witches?" Diviners had to be called into the issue. As expected in patriarchy, the four diviners identified two ladies as the culprits. Compounding the problem, two other female house-helps also voluntarily 
confessed to be responsible for the deaths. No male was accused and none confessed. All four were immediately ostracized by the head of the clan. But this did not solve the problem as James, the last of the Ogbeides died afterwards of symptoms similar to those that killed some of his relatives. Immediately James was buried, Michael, the second son of the Ogbeides had no option than to run to America to join his eldest brother. On the advice of his elder brother, Julius, he sold his father's house and car and funded his trip to America, bidding farewell to the 'demon infected town (Ekpoma)'. On the $7^{\text {th }}$ of January, 2007, Michael arrived in America. He had barely settled down when he fell ill with the characteristic family symptoms. Michael concluded that the witches have trailed him to America. But Julius, his eldest brother, rushed him to the hospital where he tested positive to full blown AIDS. Michael also died. ${ }^{23}$

Four women, (two fingered by the diviner, two admitted responsibility for the multiple deaths in the family) were ostracised from their legitimate community for an offence they apparently knew nothing of. What of the self-confessed witches someone may ask? In the first place, we do not know under what circumstances the confession was made but we do know that witchcraft suspects are subjected to harrowing ordeal. Many are bullied into involuntary admittance of guilt in exchange for immediate relief.

Moreover, Israel Aina, of the department of Mental Health, University of Benin Teaching Hospital, identified schizophrenia, mania, depression, dementia and drug abuse as possible health conditions under which a victim may claim or admit responsibility for an offence he/she may not have committed. In any case, the tension in Ogbeide's family was sufficient to trigger any of these ailments. Assuming that these women were innocent of the charges

${ }^{23}$ C. O. Isiramen, "HIV/AIDS and Witchcraft Belief in the Nigerian Society: A Socio-cultural/Religious Response" in C.O. Isiramen, et al, eds. Religion and the Nigerian Nation: Some Topical Issues, Ibadan: En-Joy Press and Books, 2011, 275 - 275. 
of causing multiple deaths in a family, certain questions are pertinent. Will they be reintegrated into their community? If yes, are they not entitled to compensation? Who pays the compensation? In an environment where people believe the report of native doctors more than laboratory findings, will the women regain their lost respect in social relationships? These are questions that confront all who insist on traditional autopsy as some persons would call it. The four women were lucky in the sense that they were not killed but are alive and vindicated. Many others were not so lucky.

\section{Conclusion}

Our discussion above shows that necromantic practice and divination are common practices among the Ika and the Obolo Andoni. On the contrary, poison ordeal which is common among the Ika is not known among the Obolo. These practices (necromancy, divination and poison ordeal) are metaphysical responses to what is considered to be the unknown cause(s) of untimely death and miserable conditions of man. For the Ika on the one hand, unpleasant happenings are attributed to the mischief of witches or sorceress who must be identified, exposed and severely punished for sanity and safety to reign in the community. No doubt, efforts to discourage the activities of witches and sorcerers cannot be adjudged a failure. This is because people who respect good names try as much possible to avoid the possession of the power of witchcraft and safe-guard their children from being initiated. For the Obolo on the other hand, causes of death are attributed to anger either from the gods, unappeased ancestors or the invitation of the salt water gods.

The practice of witchcraft, sorcery and the processes of identifying them have elicited many and varied reactions. What appears to be unanimous is the fact that it is not enough to identify and punish culprits. The hard reality is that misfortune is part and parcel of life, and scapegoatism cannot extirpate it. Job realized this fact thousands of years ago when he surmised that, "man born of woman is of few days and full of trouble (Job 14:1 NIV). Until and unless activities aimed at ascertaining the causes of death among the Ika and Obolo are dispassionately appraised. Witch-hunting 
among the people will sooner than later become an ill wind that both the innocent and the guilty cannot escape.

\section{References}

Ashibuogu, U. E. (1990). Suicide in Christianity and Igbo culture: A comparative study (unpublished), B A Thesis. Lagos State University

Awajiusuk, F. J. (2006). Religio-cultural change in obolo (unpublished), MA Thesis, Department of Religious and Cultural Studies. University of Port Harcourt.

Ehianu, W. E. (1997). Ecumenism in owa land. (unpublished). Ekpoma: Edo State University.

Horton, R. (April 1971). “African conversion”. Africa. 41(2).

Inagbor, V. (1988). The mythological concept of death and after life: An evaluation of aspect of okulusho metaphysics" (unpublished), MA Thesis. Edo State University, Ekpoma.

Isiramen, C. O. (2010). Necromancy: A socio-religious practice among Otuo people of Nigeria. Epha Ekpoma Journal of Religious Studies, (6).

Isiramen, C. O. (2011). HIV/AIDS and Witchcraft belief in the Nigerian society: A Socio-cultural/Religious Response, C. O. Isiramen, et al, eds. Religion and the Nigerian Nation: Some Topical Issues. Ibadan: EnJoy Press and Book.

Middleton, J. (1960). Lugbara religion. Oxford: International African Institute.

Nadel, S. F. (1954). Nupe religion. London: Routledge and Kegan Paul Ltd.

Oviah, B. (2005). Personal Interview, Traditional chief. Owanta: Owa land.

Rose, H. J. (1971). Death- in encyclopaedia of religion and ethics, (IV). New York: Charles Scribner's Sons. 